\title{
Halomonas almeriensis sp. nov., a moderately halophilic, exopolysaccharide-producing bacterium from Cabo de Gata, Almería, south-east Spain
}

\author{
Correspondence \\ Emilia Quesada \\ equesada@ugr.es
}

\author{
Fernando Martínez-Checa, Victoria Béjar, M. José Martínez-Cánovas, \\ Inmaculada Llamas and Emilia Quesada
}

Microbial Exopolysaccharide Research Group, Department of Microbiology, Faculty of
Pharmacy, Campus Universitario de Cartuja s/n, University of Granada, 18071 Granada, Spain

\begin{abstract}
Halomonas almeriensis sp. nov. is a Gram-negative non-motile rod that was isolated from a saltern in the Cabo de Gata-Nijar wildlife reserve in Almería, south-east Spain. It is moderately halophilic, capable of growth at concentrations of $5-25 \% \mathrm{w} / \mathrm{v}$ sea-salt mixture, the optimum being $7.5 \% \mathrm{w} / \mathrm{v}$. It is chemo-organotrophic and strictly aerobic, produces catalase but not oxidase, does not produce acid from any sugar and does not synthesize hydrolytic enzymes. The most notable difference between this micro-organism and other Halomonas species is that it is very fastidious in its use of a carbon source. It forms mucoid colonies due to the production of an exopolysaccharide. Its $\mathrm{G}+\mathrm{C}$ content is $63.5 \mathrm{~mol} \%$. A comparison of $16 \mathrm{~S} \mathrm{rRNA}$ gene sequences confirmed its relationship to Halomonas species. The most closely related species is Halomonas halmophila with $95.8 \%$ similarity between their $16 \mathrm{~S}$ rRNA gene sequences. DNA-DNA hybridization with $H$. halmophila is $10 \cdot 1 \%$. Its major fatty acids are $18: 1 \omega 7 c, 16: 0$, $16: 1 \omega 7 c / 15: 0$ iso $2-\mathrm{OH}, 12: 03-\mathrm{OH}, 12: 0,11$-methyl $18: 1 \omega 7 c$ and $10: 0$. The proposed

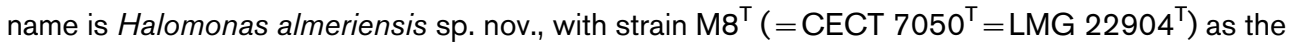
type strain.
\end{abstract}

The genus Halomonas, belonging to the family Halomonadaceae within the class 'Gammaproteobacteria', contains to date 32 species of moderately halophilic bacteria, most of which have been isolated from hypersaline habitats (Dobson \& Franzmann, 1996; Mata et al., 2002; Ventosa et al., 1998; Vreeland et al., 1980). Taxonomically Halomonas is a heterogeneous bacterial group. On the basis of $16 \mathrm{~S}$ and 23S rRNA gene sequences, Arahal et al. (2002) have established three clearly distinguishable phylogenetic groups, in addition to which another three groups can also be identified by phenotypic studies, according to their capacity to produce acids from glucose and their use of a variety of compounds as sole sources of carbon and energy (Mata et al., 2002). Some of the Halomonas species, including Halomonas eurihalina, Halomonas maura, Halomonas

Published online ahead of print on 13 May 2005 as DOI 10.1099/ ijs.0.63676-0.

The GenBank/EMBL/DDBJ accession number for the $16 \mathrm{~S}$ rRNA gene sequence of strain $M^{\top}{ }^{\top}$ is $A Y 858696$.

A dendrogram based on the simple-matching coefficient and UPGMA method, a neighbour-joining tree showing the phylogenetic relationships between $H$. almeriensis and other Halomonas species and taxa of Gram-negative halophilic bacteria, and a transmission electron micrograph showing the morphology of strain $\mathrm{M}^{\top}$ are available as supplementary material in IJSEM Online. ventosae and Halomonas anticariensis, which were isolated and characterized by our research group (Quesada et al., 1990; Bouchotroch et al., 2001; Martínez-Cánovas et al., $2004 a, b)$, produce extracellular polysaccharides with potential biotechnological applications (Calvo et al., 2002; Béjar et al., 1998; Martínez-Checa et al., 2002; Arias et al., 2003; Quesada et al., 2004).

We describe here a novel exopolysaccharide-producing species belonging to the genus Halomonas, with the proposed name Halomonas almeriensis.

Strain $\mathrm{M}^{\mathrm{T}}$ was isolated from a water sample taken from a saltern in the Cabo de Gata-Nijar wildlife reserve in the province of Almería in south-east Spain during a wide range of samplings made by our research group in 18 hypersaline habitats in Spain and Morocco (Martínez-Cánovas et al., 2004c). It was routinely kept and grown at $32^{\circ} \mathrm{C}$ in $\mathrm{MY}$ medium (Moraine \& Rogovin, 1966) with $7 \cdot 5$ \% w/v marine salts (Rodríguez-Valera et al., 1981).

Phenotypic characterization, on the basis of 112 tests, was done as described by Mata et al. (2002). We compared the novel strain with Halomonas species using the software TAXAN (Information Resources Group, Maryland Biotechnology Institute, University of Maryland, College Park, 
Table 1. Characteristics that distinguish $H$. almeriensis from other phylogenetically related type strains of the genus Halomonas

1, H. almeriensis CECT $7050^{\mathrm{T}}$; 2, H. halmophila ATCC $19717^{\mathrm{T}}$; 3, Halomonas elongata CECT $4279^{\mathrm{T}} ; 4$, H. eurihalina ATCC $49336^{\mathrm{T}}$. Data from this study and from Dobson et al. (1990), Mata et al. (2002) and Vreeland et al. (1980).

\begin{tabular}{|c|c|c|c|c|}
\hline Characteristic & 1 & 2 & 3 & 4 \\
\hline Morphology & Short rod & Rod & Rod & Short rod \\
\hline Exopolysaccharide & + & - & - & + \\
\hline Motility & - & + & + & - \\
\hline Oxidase & - & + & - & - \\
\hline Sea-salt range $(\%, w / v)$ & $5-25$ & $3-25$ & $0-20$ & $0 \cdot 5-25$ \\
\hline Sea-salt optimum $(\%$, w/v) & $7 \cdot 5$ & $7 \cdot 5$ & $3-8$ & $7 \cdot 5$ \\
\hline Temperature range $\left({ }^{\circ} \mathrm{C}\right)$ & $15-37$ & $15-45$ & $4-45$ & $4-45$ \\
\hline \multicolumn{5}{|l|}{ Acid from: } \\
\hline Adonitol & - & + & - & - \\
\hline L-Arabinose & - & + & + & - \\
\hline D-Fructose & - & + & - & - \\
\hline D-Galactose & - & + & - & - \\
\hline D-Glucose & - & + & + & - \\
\hline myo-Inositol & - & + & - & - \\
\hline Lactose & - & + & + & - \\
\hline Maltose & - & + & + & - \\
\hline D-Mannitol & - & + & + & - \\
\hline D-Mannose & - & + & - & - \\
\hline D-Melezitose & - & + & - & - \\
\hline D-Rhamnose & - & + & - & - \\
\hline Sucrose & - & + & + & - \\
\hline D-Salicin & - & + & + & - \\
\hline D-Sorbitol & - & - & + & - \\
\hline Sorbose & - & + & - & - \\
\hline D-Trehalose & - & + & + & - \\
\hline \multicolumn{5}{|l|}{ Hydrolysis of: } \\
\hline Aesculin & - & - & - & + \\
\hline Gelatin & - & - & - & + \\
\hline Tween 20 & - & + & - & + \\
\hline Tween 80 & - & - & - & + \\
\hline Tyrosine & - & - & - & + \\
\hline ONPG & - & - & + & + \\
\hline Urea & - & - & + & + \\
\hline Pigment from tyrosine & - & - & - & + \\
\hline $\mathrm{H}_{2} \mathrm{~S}$ production & - & + & + & + \\
\hline Nitrate reduction & - & - & + & + \\
\hline Respiration on nitrate & - & - & + & - \\
\hline Gluconate oxidation & + & - & + & + \\
\hline \multicolumn{5}{|l|}{ Growth on: } \\
\hline Agar cetrimide & - & - & + & + \\
\hline Aesculin & - & + & - & - \\
\hline L-Arabinose & - & - & + & + \\
\hline D-Cellobiose & - & + & + & + \\
\hline D-Fructose & - & + & + & + \\
\hline D-Galactose & - & + & + & + \\
\hline D-Glucose & - & + & + & + \\
\hline Lactose & - & + & + & + \\
\hline Maltose & - & + & - & + \\
\hline
\end{tabular}

Table 1. cont.

\begin{tabular}{|c|c|c|c|c|}
\hline Characteristic & 1 & 2 & 3 & 4 \\
\hline D-Mannose & - & + & + & + \\
\hline D-Melezitose & - & + & + & + \\
\hline D-Salicin & - & - & - & + \\
\hline D-Trehalose & - & + & + & + \\
\hline Acetate & - & + & + & + \\
\hline Citrate & - & + & + & + \\
\hline Formate & - & + & - & - \\
\hline Fumarate & - & - & + & + \\
\hline Gluconate & + & - & + & + \\
\hline Malonate & - & - & + & + \\
\hline Propionate & - & - & + & + \\
\hline Succinate & - & - & + & + \\
\hline Adonitol & - & - & + & + \\
\hline Ethanol & - & - & + & - \\
\hline Glycerol & - & + & - & - \\
\hline myo-Inositol & - & - & + & + \\
\hline D-Mannitol & - & - & + & + \\
\hline Sorbitol & - & + & + & + \\
\hline L-Histidine & - & + & + & + \\
\hline DL-Isoleucine & - & - & + & + \\
\hline L-Lysine & - & - & + & + \\
\hline L-Valine & - & + & + & + \\
\hline \multicolumn{5}{|l|}{ Susceptibility to: } \\
\hline Amoxicillin $(25 \mu \mathrm{g})$ & + & + & - & - \\
\hline Ampicillin $(10 \mu \mathrm{g})$ & + & + & - & - \\
\hline Carbenicillin $(100 \mu \mathrm{g})$ & + & + & - & - \\
\hline Erythromycin $(15 \mu \mathrm{g})$ & + & - & + & + \\
\hline Nalidixic acid $(30 \mu \mathrm{g})$ & - & + & + & + \\
\hline Polymyxin B (300 IU) & - & + & - & + \\
\hline Streptomycin $(10 \mu \mathrm{g})$ & + & + & + & - \\
\hline Sulphamide $(250 \mu \mathrm{g})$ & - & + & + & + \\
\hline $\mathrm{G}+\mathrm{C}$ content $(\mathrm{mol} \%)$ & $63 \cdot 5$ & $63 \cdot 0$ & $60 \cdot 5$ & $59 \cdot 1-65 \cdot 7$ \\
\hline
\end{tabular}

USA) based on numerical analysis. The dendrogram obtained by the simple-matching coefficient $\left(S_{\mathrm{SM}}\right)$ (Sokal \& Michener, 1958) and UPGMA method (Sneath \& Sokal, 1973) (see Supplementary Fig. S1 in IJSEM Online) shows that strain $\mathrm{Mr}^{\mathrm{T}}$ was related to the non-acid-producing group of Halomonas species (Mata et al., 2002), although it shares less than $63 \%$ similarity with them. This low similarity can be put down to the fact that strain $\mathrm{M}^{\mathrm{T}}$ is extremely fastidious nutritionally. The main phenotypic differences between $H$. almeriensis $\left(\mathrm{M} 8^{\mathrm{T}}\right)$ and its nearest phylogenetically related strains of the genus Halomonas are shown in Table 1.

The $\mathrm{G}+\mathrm{C}$ content of the DNA of strain $\mathrm{M} 8^{\mathrm{T}}$ was estimated from the midpoint value $\left(T_{\mathrm{m}}\right)$ of the DNA thermal denaturation profile, as described by Marmur \& Doty (1962) and Ferragut \& Leclerc (1976). The G $+C$ content of the DNA of the novel strain was $63.5 \mathrm{~mol} \%$, within the range proposed for Halomonas species of 52-68 mol\% (Franzmann et al., 1988). 
A partial fragment of the 16S rRNA gene was amplified by PCR using the protocol of Saiki et al. (1988). The forward primer, 16F27 (5'-AGAGTTTGATCATGGCTCAG-3'), annealed at positions 8-27 and the reverse primer, 16R1488 (5'-CGGTTACCTTGTTAGGACTTCACC- $3^{\prime}$ ) (both from Pharmacia), annealed at the complement of positions 1511-1488 (Escherichia coli numbering according to Brosius et al., 1978). To complete the sequence we designed an internal primer, 5'-GAGGATGATCAGCCACACTG-3', which annealed at positions 401-421. The PCR product was purified using the GFX PCR DNA and Gel Band purification kit (Amersham Biosciences). Direct sequence determinations of PCR-amplified DNAs were made with an ABI PRISM dye-terminator, cycle-sequencing, readyreaction kit (Perkin-Elmer) and an ABI PRISM 377 sequencer (Perkin-Elmer) according to the manufacturer's instructions. The sequence obtained (1459 bp) was compared with $16 \mathrm{~S}$ rRNA reference gene sequences retrieved from the GenBank and EMBL databases by BLAST search. Phylogenetic and molecular evolutionary analyses were conducted using MEGA version 3.0 (Kumar et al., 2004) after multiple alignment of the data by CLUSTAL_X (Thompson et al., 1997). Distances and clustering were determined using the neighbour-joining and maximum-parsimony algorithms, and a bootstrap analysis (1000 replications) was made to determine the stability of the clusters. The neighbour-joining tree is available as Supplementary Fig. S2 in IJSEM Online. A similar result (not shown) was obtained using the maximum-parsimony algorithm. The taxa included in the tree shown in Fig. 1 represent only the nearest neighbours. Our analyses confirmed that the novel strain belongs to the genus Halomonas, is located within group 1 of Halomonas species described by Arahal et al. (2002) and shares $95 \cdot 8 \% 16 \mathrm{~S}$ rRNA gene sequence similarity with Halomonas halmophila (Dobson et al., 1990). The
$16 \mathrm{~S}$ rRNA gene fragment analysed contains the 15 signature nucleotides defined for the family Halomonadaceae (Dobson \& Franzmann, 1996).

DNA-DNA hybridization was carried out according to the method of Lind \& Ursing (1986) with the modifications introduced by Ziemke et al. (1998) and Bouchotroch et al. (2001). The result shows the low hybridization $(10 \cdot 1 \%)$ with $H$. halmophila, which was chosen on the basis of our phylogenetic study as being the most closely related Halomonas species.

The fatty acids were analysed at DSMZ (Deutsche Sammlung von Mikroorganismen und Zellkulturen $\mathrm{GmbH}$ ) by high-resolution GLC using a moist pellet of the cells obtained from a culture in MY medium supplemented with $7 \cdot 5 \%$ w/v sea-salt mixture. Strain $\mathrm{M}^{\mathrm{T}}$ shows a combination of fatty acids found in other species of Halomonas (Dobson \& Franzmann, 1996) (see species description), although it also contains a relatively high proportion of $10: 0(2 \cdot 11 \%), 12: 0(1 \cdot 22 \%)$ and 11-methyl $18: 1 \omega 7 c$ $(2 \cdot 75 \%)$.

A transmission electron micrograph showing the morphology and cell size of strain $\mathrm{Mr}^{\mathrm{T}}$ and the presence of an extracellular polymer that is released into the external medium is available as Supplementary Fig. S3 in IJSEM Online. The TEM method used is fully described by Bouchotroch et al. (2001).

On the basis of phylogeny, DNA-DNA hybridization, fatty acid composition and phenotypic differences between the novel and previously described species within the genus Halomonas, we consider that strain $\mathrm{M}^{\mathrm{T}}$ represents a novel species, for which we propose the name Halomonas almeriensis sp. nov.

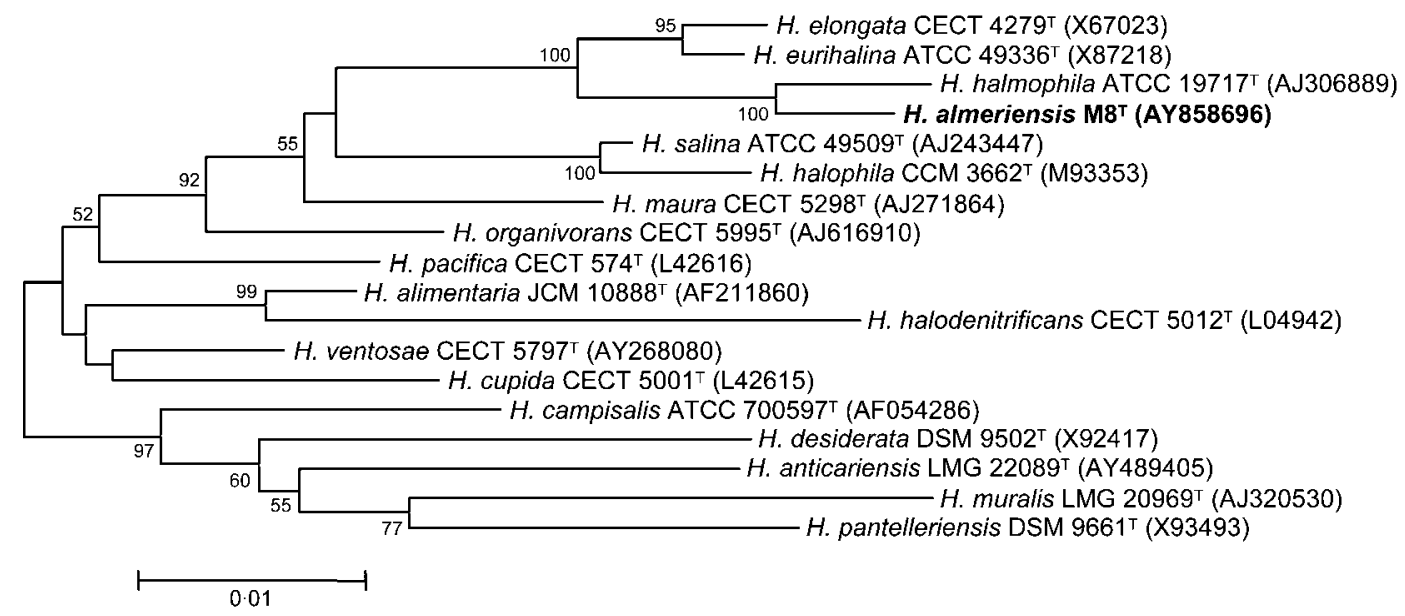

Fig. 1. Phylogenetic relationships between Halomonas almeriensis and other related Halomonas species. The tree was constructed using the neighbour-joining algorithm based on 16S rRNA gene sequences. Only bootstrap values greater than $50 \%$ are shown (1000 replications). Bar, $1 \%$ estimated sequence divergence. 


\section{Description of Halomonas almeriensis sp. nov.}

Halomonas almeriensis (al.me.ri.en'sis. N.L. fem. adj. almeriensis denizen of the province of Almería in southeast Spain, where the strain was isolated).

Cells are Gram-negative, non-motile rods, $2-2.5 \times 0.75 \mu \mathrm{m}$, occurring singly or in pairs. They accumulate poly- $\beta$ hydroxyalkanoates and produce exopolysaccharide. Colonies are round, convex, creamy-white and mucoid. Their growth pattern is uniform in a liquid medium. It is moderately halophilic, capable of growth in salt concentrations (mixture of sea salts) of $5-25 \% \mathrm{w} / \mathrm{v}$. It grows at $15-37^{\circ} \mathrm{C}$ and $\mathrm{pH} 6-10$. It is chemo-organotrophic. Its metabolism is respiratory with oxygen as the terminal electron acceptor. The cells do not grow anaerobically in the presence of nitrate, nitrite or fumarate. Catalase is produced but not oxidase. It does not produce acids from sugars. Indole, methyl red and Voges-Proskauer are negative. It does not hydrolyse starch, aesculin, gelatin, casein, Tween 20, Tween 80, DNA or tyrosine. It produces phosphatase and grows on MacConkey agar, but does not produce phenylalanine deaminase, urease, ONPG or lecithinase. Gluconate is oxidized. It does not produce pigment from tyrosine, $\mathrm{H}_{2} \mathrm{~S}$ from L-cysteine, grow on cetrimide agar or lyse blood. D-Gluconate is acceptable as a sole carbon energy source, whereas aesculin, L-arabinose, Dcellobiose, D-fructose, D-galactose, D-glucose, lactose, maltose, D-mannose, D-melezitose, salicin, starch, D-trehalose, D-xylose, acetate, citrate, formate, fumarate, malonate, propionate, succinate, adonitol, ethanol, glycerol, myoinositol, D-mannitol and sorbitol are not. L-Alanine and L-serine are used as sole sources of carbon, nitrogen and energy, whereas L-histidine, DL-isoleucine, L-lysine, L-methionine and L-valine are not. It is susceptible to amoxicillin $(25 \mu \mathrm{g})$, ampicillin $(10 \mu \mathrm{g})$, carbenicillin $(100 \mu \mathrm{g})$, cefotaxime $(30 \mu \mathrm{g})$, cefoxitin $(30 \mu \mathrm{g})$, chloramphenicol $(30 \mu \mathrm{g})$, erythromycin $(15 \mu \mathrm{g})$, kanamycin $(30 \mu \mathrm{g})$, nitrofurantoin $(300 \mu \mathrm{g})$, rifampicin $(30 \mu \mathrm{g})$, streptomycin $(10 \mu \mathrm{g})$, tobramycin $(10 \mu \mathrm{g})$ and trimethoprim/ sulfamethoxazole $(1 \cdot 25 / 23 \cdot 75 \mu \mathrm{g})$. It is resistant to nalidixic acid $(30 \mu \mathrm{g})$, polymyxin B (300 IU) and sulphamide $(250 \mu \mathrm{g})$. Principal fatty acids (greater than $1 \%$ ) are $18: 1 \omega 7 c(50 \cdot 66 \%)$; 11 -methyl $18: 1 \omega 7 c(2 \cdot 75 \%) ; 16: 0$ $(21 \cdot 08 \%) ; 16: 1 \omega 7 c / 15: 0$ iso $2-\mathrm{OH} \quad(14 \cdot 16 \%) ; 12: 0$ $3-\mathrm{OH}(5 \cdot 64 \%) ; 12: 0(1 \cdot 22 \%)$ and $10: 0(2 \cdot 11 \%)$. The DNA G + C content of the type strain is $63.5 \mathrm{~mol} \%\left(T_{\mathrm{m}}\right.$ method).

The type strain, $\mathrm{M}^{\mathrm{T}}\left(=\right.$ CECT $\left.7050^{\mathrm{T}}=\mathrm{LMG} 22904^{\mathrm{T}}\right)$, was isolated from a hypersaline water sample taken from a saltern at Cabo de Gata (Almería, south-east Spain).

\section{Acknowledgements}

This research was supported by grants from the Dirección General de Investigación Científica y Técnica (BOS2003-00498) and from the Plan Andaluz de Investigación, Spain. Thanks go to our colleague Dr J. Trout for revising our English text.

\section{References}

Arahal, D. R., Ludwig, W., Schleifer, K. H. \& Ventosa, A. (2002). Phylogeny of the family Halomonadaceae based on $23 \mathrm{~S}$ and $16 \mathrm{~S}$ rDNA sequence analyses. Int J Syst Evol Microbiol 52, 241-249.

Arias, S., del Moral, A., Ferrer, M. R., Quesada, E. \& Béjar, V. (2003). Mauran, an exopolysaccharide produced by the halophilic bacterium Halomonas maura, with a novel composition and interesting properties for biotechnology. Extremophiles 7, 319-326.

Béjar, V., Llamas, I., Calvo, C. \& Quesada, E. (1998). Characterization of exopolysaccharides produced by 19 halophilic strains of the species Halomonas eurihalina. J Biotechnol 61, 135-141.

Bouchotroch, S., Quesada, E., del Moral, A., Llamas, I. \& Béjar, V. (2001). Halomonas maura sp. nov., a novel moderately halophilic, exopolysaccharide-producing bacterium. Int J Syst Evol Microbiol 51, 1625-1632.

Brosius, J., Palmer, M. L., Kennedy, P. J. \& Noller, H. F. (1978). Complete nucleotide sequence of a $16 \mathrm{~S}$ ribosomal RNA gene from Escherichia coli. Proc Natl Acad Sci U S A 75, 4801-4805.

Calvo, C., Martínez-Checa, F., Toledo, F. L., Porcel, J. \& Quesada, E. (2002). Characteristics of bioemulsifiers synthesised in crude oil media by Halomonas eurihalina and their effectiveness in the isolation of bacteria able to grow in the presence of hydrocarbons. Appl Microbiol Biotechnol 60, 347-351.

Dobson, S. J. \& Franzmann, P. D. (1996). Unification of the genera Deleya (Baumann et al. 1983), Halomonas (Vreeland et al. 1980), and Halovibrio (Fendrich 1988) and the species Paracoccus halodenitrificans (Robinson and Gibbons 1952) into a single genus, Halomonas, and placement of the genus Zymobacter in the family Halomonadaceae. Int J Syst Bacteriol 46, 550-558.

Dobson, S. J., James, S. R., Franzmann, P. D. \& McMeekin, T. A. (1990). Emended description of Halomonas halmophila (NCMB $1971^{\mathrm{T}}$ ). Int J Syst Bacteriol 40, 462-463.

Ferragut, C. \& Leclerc, H. (1976). Étude comparative des méthodes de détermination du $\mathrm{T}_{\mathrm{m}}$ de l'ADN bacterien. Ann Microbiol 127A, 223-235 (in French).

Franzmann, P. D., Wehmeyer, U. \& Stackebrandt, E. (1988). Halomonadaceae fam. nov., a new family of the class Proteobacteria to accommodate the genera Halomonas and Deleya. Syst Appl Microbiol 11, 16-19.

Kumar, S., Tamura, K. \& Nei, M. (2004). MEGA3: Integrated software for Molecular Evolutionary Genetics Analysis and sequence alignment. Brief Bioinform 5, 150-163.

Lind, E. \& Ursing, J. (1986). Clinical strains of Enterobacter agglomerans (synonyms: Erwinia herbicola, Erwinia milletiae) identified by DNA-DNA-hybridization. Acta Pathol Microbiol Immunol Scand Sect B 94, 205-213.

Marmur, J. \& Doty, P. (1962). Determination of the base composition of deoxyribonucleic acid from its thermal denaturation temperature. J Mol Biol 5, 109-118.

Martínez-Cánovas, M. J., Quesada, E., Llamas, I. \& Béjar, V. (2004a). Halomonas ventosae sp. nov., a moderately halophilic, denitrifying, exopolysaccharide-producing bacterium. Int J Syst Evol Microbiol 54, 733-737.

Martínez-Cánovas, M. J., Béjar, V., Martínez-Checa, F. \& Quesada, E. (2004b). Halomonas anticariensis sp. nov., from Fuente de Piedra, a saline-wetland wildfowl reserve in Málaga, southern Spain. Int J Syst Evol Microbiol 54, 1329-1332.

Martínez-Cánovas, M. J., Quesada, E., Martínez-Checa, F. \& Béjar, V. (2004c). A taxonomic study to establish the relationship between exopolysaccharide-producing bacterial strains living in diverse hypersaline habitats. Curr Microbiol 48, 348-353. 
Martínez-Checa, F., Toledo, F. L., Vilchez, R., Quesada, E. \& Calvo, C. (2002). Yield production, chemical composition, and functional properties of emulsifier H28 synthesized by Halomonas eurihalina strain H-28 in media containing various hydrocarbons. Appl Microbiol Biotechnol 58, 358-363.

Mata, J. A., Martínez-Cánovas, J., Quesada, E. \& Béjar, V. (2002). A detailed phenotypic characterisation of the type strains of Halomonas species. Syst Appl Microbiol 25, 360-375.

Moraine, R. A. \& Rogovin, P. (1966). Kinetics of polysaccharide B1459 fermentation. Biotechnol Bioeng 8, 511-524.

Quesada, E., Valderrama, M. J., Bejar, V., Ventosa, A., Gutierrez, M. C., Ruiz-Berraquero, F. \& Ramos-Cormenzana, A. (1990) Volcaniella eurihalina gen. nov., sp. nov., a moderately halophilic nonmotile Gram-negative rod. Int J Syst Bacteriol 40, 261-267.

Quesada, E., Béjar, V., Ferrer, M. R. \& 8 other authors (2004).

Moderately halophilic, exopolysaccharide-producing bacteria. In Halophilic Microorganisms, pp. 297-314. Edited by A. Ventosa. Heidelberg: Springer.

Rodríguez-Valera, F., Rúiz-Berraquero, F. \& Ramos-Cormenzana, A. (1981). Characteristics of the heterotrophic bacterial populations in hypersaline environments of different salt concentrations. Microb Ecol 7, 235-243.
Saiki, R. K., Gelfand, D. H., Stoffel, S., Scharf, S. J., Higuchi, R., Horn, G. T., Mullis, K. B. \& Erlich, H. A. (1988). Primer-directed enzymatic amplification of DNA with a thermostable DNA polymerase. Science 239, 487-491.

Sneath, P. H. A. \& Sokal, R. R. (1973). Numerical Taxonomy. The Principles and Practice of Numerical Classification. San Francisco: Freeman, Williams \& Wilkins.

Sokal, R. R. \& Michener, C. D. (1958). A statistical method for evaluating systematic relationships. Univ Kansas Sci Bull 38, 1409-1438.

Thompson, J. D., Gibson, T. J., Plewniak, K., Jeanmougin, F. \& Higgins, D. G. (1997). The CLUSTAL_X Windows interface: flexible strategies for multiple sequence alignment aided by quality analysis tools. Nucleic Acids Res 25, 4876-4882.

Ventosa, A., Nieto, J. J. \& Oren, A. (1998). Biology of moderately halophilic aerobic bacteria. Microbiol Mol Biol Rev 62, 504-544.

Vreeland, R. H., Litchfield, C. D., Martin, E. L. \& Elliot, E. (1980). Halomonas elongata, a new genus and species of extremely salttolerant bacteria. Int J Syst Bacteriol 30, 485-495.

Ziemke, F., Höfle, M. G., Lalucat, J. \& Rosselló-Mora, R. (1998). Reclassification of Shewanella putrefaciens Owen's genomic group II as Shewanella baltica sp. nov. Int J Syst Bacteriol 48, 179-186. 